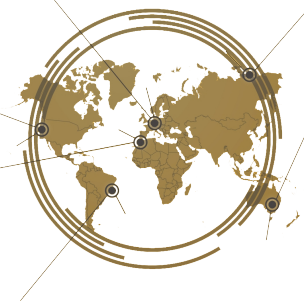

\title{
Self-organized learning environment teaching strategy for ELT in Merdeka Belajar concept for high school students in Indonesia
}

\author{
Muhammad Anis, Choiril Anwar* \\ English Language Education Study Program, Universitas Islam Sultan Agung, Semarang, Indonesia
}

As the development of the industrial revolution takes place, disruptions are happening constantly in almost every major sector of the current industries. Companies and organizations complained about the competencies of the graduates entering the work force. This matter questions the readiness of the education system in preparing the students for the real world. Problems in education such as the regulations, strict policies and instructions from the government are undermining the role of the teachers to do what they think best for their students. This standardization has harmed the motivation and enthusiasm to learn, especially in English language class. Lack of motivation and English Language competency could harm students' opportunity in accessing the vast global network of knowledge. Merdeka Belajar and SOLE are the promising alternatives in improving ELT. This article is somewhat a position paper trying to clear one side of a debatable opinion about a hot issue. It aims to persuade the reader that our opinion is valid and defensible. In doing so, we then separate the discussion into several parts regarding the analysis of concepts of Merdeka Belajar and SOLE (Self-Organized Learning Environment) related to ELT and motivation in language learning, as well as innovation in education.

Keywords: SOLE teaching strategy, Freedom to Learn, TEFL, Merdeka Belajar

\section{INTRODUCTION}

OPEN ACCESS ISSN 25033492 (online)

*Correspondence:

Choiril Anwar

choirilanwar@unissula.ac.id

Received: 10th August 2020

Accepted: 7 th october 2020

Published: 15th October 2020

Citation:

Anis $M$ and Anwar C (2020) Self-organized learning environment teaching strategy for ELT in Merdeka

Belajar concept for high school students in Indonesia.

J. Eng. Educ. Society. 5:2. doi: 10.21070/jees.v5i2.869
The need for a country to develop and to be sustainable depends on the quality of the human resources available and their ability to innovate. Hence, the quality of human resources depends on the quality of education as well as their motivation to learn and develop. In this fast-paced changing unpredictable globalized world, education must be comprehensive, sustainable and must continuously evolve to meet the challenges in the present and the future. Henceforth, lifelong learning should always be the main values that should be taught in schools. However, learning has become more formalized as humanity has developed the systematic way of thinking and problem-solving (Farenga and Ness, 2005). As learning is becoming more formalized and institutionalized, society often forgot that learning is not only confined in a room or space. It can be done outside of schools or other informal institution, organization or programs. As this mindset grows within the society, they often neglect the soft skills that enable humanity to survive, the skills that help human to work, to learn and to live better. The average main focus of the society is on the hard skills that re required for their dream job. For example, accounting, law, business, medicine, and etc. Henceforth, lifelong learn ing was basically misunderstood. Implicitly, Toffler (1970) has implied that lifelong learning is essen tial for humans 
to adapt to different times and environment. It is what helps humans to survive, innovate and to accommodate to changes. This is also why it is constituted in the Republic Indonesian Law No. 2, 1989, which is to prepare individuals to face the challenges of the present and the future.

The problem with today's education system is that it has already been standardized, rigid, and it has not been effective in preparing individuals for the competencies of the future nor the current status quo. Big companies such as Cisco, Intel and Microsoft are concerned with the graduates that are entering the workforce with the skills that did not prepare them for employment in the digital age (Griffin and Care, 2015). Moreover, modern artificial intelligence has become extremely sophisticated that it has already automated the manufacturing industry and now it is slowly taking over the service industry (Salomons and Salomons, 2018; Bartodziej, 2017). It is a matter of time where labor work or even services could be replaced by machines. In addition to that, Andrew Wycoff (the director of OECD's directorate for science, technology and innovation) and Karine Perset (Economist in OECD's digital economy policy division) has stated in Anderson et al. (2018) that in twelve years from now, disruptions are happening in every sector of all major industries due to automation. To be able to constantly develop and evolve the way we perform will help anticipate the problems that will arise in the future. Therefore, identifying the skills of the future is pertinent for people to sustain in the present and the future. The skills for the future are what is defined as the $21^{\text {st }}$ Century Skills. These skills comprise the life and career skills; information, media and technology skills; and the learning and innovation skills. These skills are identified and formulated from a collective result of surveys conducted by various organizations in companies and institutions to find out the demand of skills that are needed for the future (Griffin et al., 2012; Larson and Miller, 2011; Rotherham and Willingham, 2010).

From the explanation above, the mismatch between the work and life condition with the education taught in schools are not relevant to this time and thus it is costing the efficiency of time and energy for companies or individuals to adapt to the current status quo. Therefore, there is an urgency to improve the quality of education to be able to cater the needs and demand of the current industry and the future. If what the students are learning is obsolete, it will not allow them to develop and keep up with the current times. And thus, there will be a generation that is left behind in the development of the industry. This could pose a major threat towards a nation's economic development. This is related to Mitra (2014) statement that it is the development of the needs in the industries that changes the way of schooling. Therefore, new teaching strategies should be formulated to get the students to be prepared for the real-life experience in the present time as well as the future. This research was solely based upon the concern that could jeopardize the economic and social level of the education system in the future and the social demography in Indonesia. Therefore, Indonesia made a new initiative to tackle on the issue of the future and present employment as well as problems that might arise in the future by fixing the mindset of the teachers and the schools through the Merdeka Belajar concept in Indonesia's education system.

In order that Indonesia are able to compete globally, the skills for the future must be intensively nurtured. As motivation being one of the most determining factor in increasing a student's willingness to learn, lifelong learning will not be able to thrive within the students if there is no motivation McCombs (1991); Yilmaz and Kaygin (2018); Al Rifai (2010). Language learning and intercultural communication is also part of lifelong learning, since people always need to improve their language skills and communication skills in this globalized world. In addition to that, English is the lingua franca for communication to acquire or exchange new knowledge or experiences in most parts of the world. English language education should also be improved to be able to scale and impact effectively to create students who are globally competent. Motivation is also the significant driving factor in language learning. The role of motivation in inciting positive affective factors in accommodating language learning is arguably indisputable (BleyVroman, 1990).

Research shows that motivation drives the affective motors of the learners in language acquisition which will give the learners the drive in acquiring the language (Gardner, 1988; Wimolmas, 2012). Therefore, teachers should instill motivation towards the learners in learning the English language. The practice of Merdeka Belajar by Najelaa Shihab and the Teachers Learning Community (Komunitas Guru Belajar) has proven to increase a student's motivation in learning (Shihab and Belajar, 2017). The practices of Merdeka Belajar can be useful in the English Language Teaching as a means of an approach to improve the students' motivation in learning the English Language. Therefore, the author wishes to highlight the Merdeka Belajar Concept advocated by Najelaa Shihab - as the conceiver of this idea in an educator's perspective - to be brought into a conceptual study on how this concept could be implemented into the SOLE teaching strategy in English Language Teaching (ELT) for high school students in Indonesia.

Here, the author suggest alternative solutions in tackling the problem of the education in Indonesia in preparing the students for the present and the future, particularly in suggesting a different approach to English Language Teaching through the Self-Organized Learning Environment (SOLE) Teaching Strategy. The concept of SOLE has successfully been experimented in India by the developer of this idea, Sugata Mitra, and has ensued in positive results in academic achievement, English Pronunciation, Education objectives and selforganizing behavior (Mitra et al., 2016). This then led Sugata Mitra to be entitled as the Innovator of Education and the TED Prize Winner (Ted, 2013). This review article will be discussing on how Merdeka Belajar and SOLE synergize in improving English language teaching. 


\section{METHOD}

This review article acts almost similarly as a position paper where it tries to represent an arguable opinion about an issue in a manner of a situation like a debate. Researchers may be familiarly recognized this in the term as 'conceptual analyses in methodology'. This article intends to elaborate a conceptual study on the possibility of the implementation of SOLE in ELT through the Merdeka Belajar approach as an alternative solution to create future-ready students in a valid and defensible way of persuasion. This article adopts the method in writing a position paper from Abidah et al. (2020) while maintaining the systematic review Suprapto et al. (2017). The following is the step in writing a position paper: (1) Selecting a topic for the paper; (2) Conducting preliminary research; (3) Challenging the topic; (4) Continuing to collect supporting evidences; and (5) Creating an outline (Fleming, 2019).

\section{DISCUSSION}

In this section, the researchers group the discussion into several parts regarding the analysis of concepts of Merdeka Belajar and SOLE (Self-Organized Learning Environment) related to ELT and motivation in language learning, as well as innovation in education.

\section{Merdeka Belajar}

Merdeka Belajar (Freedom to Learn) is a new concept that needs to be tread carefully to direct the discussion objectively. Recent issues of Merdeka Belajar in Indonesia are heating up an argument that this concept is not fit to be implemented in Indonesia based on public views on the execution of the new education policy - in the implementation of Merdeka Belajar - by the new appointed minister of education, Nadiem Makarim. However, the concept of Merdeka Belajar is not a very recent phenomenon. Najelaa Shihab has coined this term earlier in 2017 along with the publication of her book 'Merdeka Belajar di Ruang Kelas. This book was also co-authored by the members of the Teachers Learning Community (Komunitas Guru Belajar) that Najelaa Shihab has founded on 2014. Unexpectedly, this concept of Merdeka Belajar has some connection with what has Ki Hajar Dewantara envisioned in his concept of Taman Siswa since around the 1920's. Upon the complexity of this Merdeka Belajar concept, the authors will discuss this concept into two parts: (1) the emergence of Merdeka Belajar; (2) the general concept of Merdeka Belajar.

\section{The emergence of Merdeka Belajar}

The progression of Indonesia's education system is very dynamic. Almost every new appointed minister of education would tend to reform the education curriculum and bring new ideas and policies towards the education system, while its pattern remains stagnant (Shihab and Belajar, 2017). It is mostly a top-down approach towards the education institutions, from the primary years up to the university education. Any government's policy on education, schools are obliged to comply with the regulations and practices that are imposed upon them in order to be recognized. The reason as to why the government are dictating how education institutions should work in every single detail is to reach the national goal in education. This top-down approach in enforcing regulations, policies and instructions to reach the national standard of learning has forced the teachers to rush the learning process of the students. Students that gets left behind are then unmotivated to learn as this rushed learning process are making learning less enjoyable (Shihab and Belajar, 2017). However, recently the education system in Indonesia is experiencing a liberation towards this top-down approach by the government's own initiative through their Merdeka Belajar Education Policy.

The concept of Merdeka belajar was initially pioneered by Najelaa Shihab along with the formation of the Teachers Learning Community (Komunitas Guru Belajar) since 2014 and she officially launched her book "Merdeka belajar di Ruang Kelas" on 2017, which was also co-authored by her members of the Teachers Learning Community (Komunitas Guru Belajar). The idea of Merdeka belajar was later on popularized by Indonesia's new minister of Education, Nadiem Makarim, on 2019 to be implemented into Indonesia's education system as a new national education policy. This Merdeka Belajar Education Policy by Nadiem Makarim revolves around 4 pillars that are foundational for the breakthrough of the "Merdeka belajar" Concept, which are; the replacement of National Standard School Examinations with the decentralized individual school assessment, the termination of National Examinations, the simplification of the Lesson Plan (RPP), and the Zoning Regulations for New Students Acceptance.

On the other hand, the Merdeka Belajar Concept by Najelaa Shihab and the Teachers Learning Community (Komunitas Guru Belajar) are initially more towards the bottom-up approach, outreaching community of teachers and empowering them to be accepting of their vulnerabilities and motivating them to learn as well as innovate teaching practices that are more suited towards the learning style of their own students. The implication of the concept of Merdeka Belajar is very versatile as it focuses on innovation and peer-to-peer sharing of their teaching practices among teachers. However, this versatility cannot compromise the three principles for the Merdeka Belajar Concept that was brought by Najelaa Shihab and the Teachers Learning Community, which are; Commitment, Independence, and Reflection. These three essential principles in the Merdeka Belajar concept are the key for teachers in unlocking the student's enthusiasm and desire to learn by giving them the freedom and the courage to dream as well as inspiring them to explore the world (Shihab and Belajar, 2017).

Here we can understand that there are differences in perspective on the Merdeka Belajar concept between Najelaa Shihab and Nadiem Makarim. The Merdeka Belajar Concept that was pioneered by Najelaa Shihab and the Teachers Learning 
Community is more towards the emancipation of teachers to be freed of the strict regulation of the government, while the Merdeka Belajar which was advocated by Nadiem Makarim is more towards educational policy to empower educators and teachers the freedom to teach as how they deem fit for their school and their students. Even though there are differences in perspective on the Merdeka Belajar Concept between these two public figures, their ideas are complimentary to one another. Further research should be made to analyze these two differences in perspective of Merdeka Belajar.

\section{Self-Organized Learning Environment (SOLE)}

It has been a norm in assuming that children need major guidance from an adult. However, today there has been a paradigm shift in learning. Learning is no longer seen as a process of the transfer of knowledge from a teacher to the students (Esteban and Peart, 2014; Sholichah, 2019). Nevertheless, it is the teachers who help the students to learn by providing facilities and situations that support them in order to build concepts and understanding of the topic independently and actively. Sugata Mitra has proven that children can teach themselves through his Hole-in-the-Wall project in India, which was presented in the 2013 TED Talk (Ted, 2013). From his Hole-in-the-Wall project, he formulated the SOLE concept which is integrated in his dream of building a School in the Cloud. His SOLE concept has given him the title as the Innovator of Education and the TED Prize winner (Ted, 2013). This then inspired teachers around the globe to create their own SOLE sessions in their respective countries or districts as part of the teachers of the School in the Cloud project. The School in the Cloud is learning and teaching platform that acts like an online school. This platform was launched at the 2014 TED conference with an objective to help accelerate the SOLE research globally to teachers or educators and share their teaching and learning experiences together.

SOLE is a concept which was developed by Sugata Mitra and the researchers at the SOLE Centre in Newcastle University. This concept was initially based upon Sugata Mitra's Hole-in-the-Wall project in which he examined the impact of a free-to-use computer, connected to the internet, which is embedded into a wall in a village with a height where it will be convenient to use by 8-13 year old. In this experiment, which was conducted for more than 5 years in India, native Indian children are able to operate a computer, which operates in English, in a short amount of time while learning the English language at the same time. This experiment was conducted in the rural villages of India which resulted in a significant improvement on the children's academic achievement. Some of the results of the following research are from several different studies quoted by Mitra et al. (2016) regarding the 'Hole-in-the-Wall' experiment. The result of the first research was done by Mitra (2005) himself - and later on experimented by DeBoer (2009) — who found out that children can learn to use computers and the internet independently, regardless of the children's language and origins. Secondly, the results of the research by Inamdar and Kulkarni (2007) proved that children can achieve their educational objectives independently related to standard school examination in computer science and mathematics; improvement in English pronunciations Mitra et al. (2003); and increase in school performance (Dangwal et al., 2014). Third, children are able to show self-organizing behavior as a result of learning in a minimally invasive environment (Dangwal and Kapur, 2008).Finally, children can show understanding related to advanced content of knowledge that is far beyond the expectations for groups of children aged from 8-13 years old (Inamdar, 2004; Mitra, 2012).

SOLE with its highly influenced Constructivism approach, this learning and teaching concept of letting the learners to take steer of their learning process gives them the ability to make meaning of the subject on their own. The teacher's role as a facilitator will only observe and supervises the students in the learning process. The students are encouraged to work together to answer questions using the internet. During the process, the students will be preoccupied by self-discovery, sharing their knowledge in a community, and spontaneity in trying to learn in the edge of chaos (Mitra, 2012). The introduction of SOLE in India's rural villages improved the comprehension of the children's English language. The children explored the contraption provided by Sugata Mitra in his Hole-in-the-Wall project as a mystery device that performs magnificent tricks which intrigued the student's curiosity. In doing so, the students are also trying to control the chaotic learning environment where all of the children want to try the little contraption while trying to solve the question given by Sugata Mitra himself (Mitra, 2014). This type of engagement proved to be effective to activate the learning mode of the students through this project.

Upon the significant improvement, there is a possibility to implement the SOLE concept in Indonesia to shift its teaching paradigm from a teacher-centered learning towards a studentcentered learning effectively. Since modern day technology is becoming more accessible, it would benefit the children of the rural areas in Indonesia to positively explore the encyclopedia of knowledge from the internet in a regulated manner that is facilitated by a teacher. The process of teaching and learning in this SOLE concept can be applied as a teaching approach to accomodate the theoretical knowledge into an experience in English Learning and Teaching. Through this approach, the learners are being immersed into the problem at hand with access to the sea of information on the internet - that is relevant to the subject - to solve that problem. Thus, the learners are directly engaged and exposed towards resources in English and try to break the language barrier. Moreover, this can increase the children's immersive engagement in technologies as a learning media for their investment in the future.

One example of learning that applies Merdeka Belajar and SOLE model is the flipped classroom (Anwar and Pratama, 2016; Anwar, 2017). This kind of learning leads students to find as much information as possible about learning materials not only in the classroom but also outside the classroom, 
especially by using technology. In addition, students can also practice learning English with their friends and teachers more freely. The teacher only needs to make sure that students enjoy it, learning process runs smoothly and as well as related to the current topic of discussion.

\section{CONCLUSION}

The results of this article reveal that Merdeka Belajar and SOLE both have noble goals which lead to the formation of a strong character for students, especially high school students. Students at this age need to have high self-confidence, independence, freedom in learning, and responsiveness to the surrounding environment. If the students do not have them, then they will not be ready enough for facing the real world as well as the future. This also will impact the sustainable develop-

\section{REFERENCES}

Abidah, A., Hidaayatullaah, H. N., Simamora, R. M., Fehabutar, D., and Mutakinati, L. (2020). The Impact of Covid-19 to Indonesian Education and Its Relation to the Philosophy of "Merdeka Belajar". Studies in Philosophy of Science and Education 1, 38-49. doi: 10.46627/sipose.v1i1.9.

Al Rifai, N. (2010). Attitude, motivation, and difficulties involved in learning the English language and factors that affect motivation in learning it. Procedia Social and Behavioral Sciences 2, 5216-5227. doi: 10.1016/j.sbspro.2010.03.849.

Anderson, J., Rainie, L., and Luchsinger, A. (2018). https://www.elon.edu/docs/ e-web/imagining/surveys/2018_survey/AI_and_the_Future_of_Humans_12_ 10_18.pdf.

Anwar, C. (2017). Flipped classroom in teaching vocabulary to EFL young learners. Conference Proceedings of The 2nd International Conference 2017 on Teaching English for Young Learners (TEYLIN): Indigenous norms to the coming age of one Asia, 109-115.

Anwar, C. and Pratama, A. (2016). Flipped classroom in teaching speaking to young learners. Proceeding of The 63rd TEFLIN International Conference" Creativity and Innovation in Language Materials Development and Language Teaching Methodology 1, 285-289.

Bartodziej, C. J. (2017). The concept industry 4.0: An empirical analysis of technologies and applications in production logistics (Berlin, Germany: Springer Gabler).

Bley-Vroman, R. (1990). What is the logical problem of foreign language learning? What is the logical problem of foreign language learning? Linguistic Analysis 20, 3-49. doi: https://doi.org/10.1017/CBO9781139524544.005.

Dangwal, R. and Kapur, P. (2008). Children's learning processes using unsupervised "hole in the wall" computers in shared public spaces. Australasian Journal of Educational Technology 24, 339-354. doi: 10.14742/ajet.1213.

Dangwal, R., Sharma, K., and Hazarika, S. (2014). Hole-in-the-Wall learning stations and academic performance among rural children in India. Journal for Multicultural Education 8, 31-53. doi: 10.1108/jme-03-2013-0006.

DeBoer, J. (2009). The relationship between environmental factors and usage behaviors at 'Hole-in-the-wall' computers. International Journal of Educational Development 29, 91-98. doi: 10.1016/j.ijedudev.2008.02.005.

Esteban, P. G. and Peart, M. T. (2014). Introducing self organized learning environments in higher education as a tool for lifelong learning. Introducing self organized learning environments in higher education as a tool for lifelong learning. E-Learning and Intercultural Competences Development in Different Countries, 413-422.

Farenga, S. J. and Ness, D. (2005). Encyclopedia of education and human development (New York: M.E. Sharpe).

Fleming, G. (2019). 5 steps to writing a position paper. 5 steps to writing a position paper. https://www.thoughtco.com/how-to-write-a-position-paper- 1857251. (Accessed on 2020-08-23)

Gardner, R. C. (1988). Attitudes and Motivation. Annual Review of Applied Linguistics 9, 135-148. doi: 10.1017/s0267190500000854 ment aspects of our nation and country. In learning English, Merdeka Belajar and SOLE are appropriate to be used as strategies to boost students' skills in English. Students who have strong self-confidence, independence and freedom in learning, and understand the situation and conditions of their environment as well as are able to manage and utilize the potential of their environment will find it very easy to learn English.

\section{AKNOWLEDGMENT}

Our deepest gratitude goes to the dean of language and communication science faculty who has supported us to come up with more valuable articles which are badly required by our government and nation and are very factual as well as actual in our academic atmosphere.

Griffin, P. and Care, E. (2015). The ATC21S method. In Assessment and Teaching of 21st Century Skills, ed. P. G. E. Care (Springer), 3-33.

Griffin, P., Care, E., and Mcgaw, B. (2012). Assessment and teaching of 21st century skills, Griffin, P., McGaw, B., and Care, E. (eds.) (Dordrecht: Springer), 1-15.

Inamdar, P. (2004). Computer skills development by children using 'hole in the wall' facilities in rural India. Australasian Journal of Educational Technology 20, 337-350. doi: 10.14742/ajet.1351.

Inamdar, P. and Kulkarni, A. (2007). Hole-In-The-Wall' computer Kiosks foster mathematics achievement - A comparative study. Journal of Educational Technology \& Society 10, 170-179.

Larson, L. C. and Miller, T. N. (2011). 21st Century Skills: Prepare Students for the Future. Kappa Delta Pi Record 47, 121-123. doi: 10.1080/00228958.2011. 10516575.

McCombs, B. L. (1991). Motivation and Lifelong Learning. Educational Psychologist 26, 117-127. doi: 10.1207/s15326985ep2602_4.

Mitra, S. (2005). Self organising systems for mass computer literacy : Findings from the ' hole in the wall' experiments. International Journal of Development Issues $4,71-81$.

Mitra, S. (2012). Beyond the Hole in the Wall. Discover the power of self-organised learning (TED Books).

Mitra, S. (2014). The future of schooling: Children and learning at the edge of chaos. Prospects 44, 547-558.

Mitra, S., Kulkarni, S., and Stanfield, J. (2016). Learning at the edge of chaos: Selforganising systems in education. The Palgrave International Handbook of Alternative Education, 227-239.

Mitra, S., Tooley, J., Inamdar, P., and Dixon, P. (2003). Improving English Pronunciation: An Automated Instructional Approach. Information Technologies and International Development 1, 75-84. doi: 10.1162/itid.2003.1.1.75.

Rotherham, A. J. and Willingham, D. T. (2010). 21st-century" skills. "21st-Century" Skills 7, 17-20.

Salomons, A. and Salomons, A. (2018). Is automation labor-displacing? Productivity growth, employment, and the labor share (No. w24871) (Cambridge: National Bureau of Economic Research).

Shihab, N. and Belajar, K. G. (2017). Merdeka belajar di ruang kelas (Tangerang Selatan: Literati \& Kampus Guru Cikal).

Sholichah, A. F. (2019). Pembelajaran Self-Organised Learning Environment (SOLE) dalam penyelesaian tugas di SMP Negeri 9 Semarang. https://lib.unnes. ac.id/33343/.

Suprapto, N., Liu, W.-Y., and Ku, C.-H. (2017). The Implementation of Multiple Intelligence in (Science) Classroom: From Empirical Into Critical. Pedagogika 126, 214-227. doi: 10.15823/p.2017.30.

Ted (2013). Sugata Mitra creates a School in the Cloud. Sugata Mitra creates a School in the Cloud. https://www.ted.com/participate/ted-prize/prizewinning-wishes/school-in-the-cloud.

Toffler, A. (1970). Future Shock (New York: Random House). 
Wimolmas, R. (2012). A survey study of motivation in English language learning of first year undergraduate students at Sirindhorn International Institute of Technology (SIIT), Thammasat University. FLLT Conference Proceedings by LITU 2, 904-915.

Yilmaz, E. and Kaygin, H. (2018). The Relation Between Lifelong Learning Tendency and Achievement Motivation. Journal of Education and Training Studies 6, 1-1. doi: 10.11114/jets.v6i3a.3141.

Conflict of Interest Statement: The authors declare that the research was conducted in the absence of any commercial or financial relationships that could be construed as a potential conflict of interest.

Copyright (๑) 2020 Anis and Anwar. This is an open-access article distributed under the terms of the Creative Commons Attribution License (CC BY). The use, distribution or reproduction in other forums is permitted, provided the original author(s) and the copyright owner(s) are credited and that the original publication in this journal is cited, in accordance with accepted academic practice. No use, distribution or reproduction is permitted which does not comply with these terms. 